\title{
BOOK-TAX DIFFERENCES, EARNINGS PERSISTENCE AND TAX PLANNING BEFORE AND AFTER THE ADOPTION OF IFRS IN BRAZIL
}

\author{
Antonio Lopo Martinez ${ }^{1}$ \\ Tatiana Bossonello Tolentino de Souza ${ }^{2}$ \\ Danilo Soares Monte-Mor ${ }^{3}$
}

\begin{abstract}
The aim of this study was to provide evidence regarding the relationship between book-tax differences (BTD), persistence of earnings and accruals and tax planning in the Brazilian scenario. The sample corresponds to all nonfinancial firms listed on the BM\&FBovespa that disclosed consolidated financial statements between 2003 and 2012, obtained from the Economática database. The sample period was chosen to straddle the year when the use of International Financial Reporting Standards (IFRS) became mandatory in Brazil. Based on the econometric models presented by Hanlon (2005) and modified by Blaylock et al. (2012), we observed the statistical significance of the regressions in Brazilian context. The coefficients of the variables present indications of less persistence of earnings, besides indicating that earnings became less persistent after adoption of IFRS. The results also provide statistical evidence that temporary large positive BTDs provide useful incremental information about the magnitude of accruals and that by examining accruals it is possible to predict the persistence of earnings and their components.
\end{abstract}

Keywords: Tax planning. Book-Tax Differences. IFRS.

\footnotetext{
E-mail: lopo@fucape.br - Fundação Instituto Capixaba de Pesquisas em Contabilidade, Economia e Finanças (FUCAPE)

${ }^{2}$ E-mail: tatianabossonello@hotmail.com - Pianna Comércio Imp. e Exp. Ltda

${ }^{3}$ E-mail: danilo@fucape.br - Fundação Instituto Capixaba de Pesquisas em Contabilidade, Economia e Finanças (FUCAPE)

- DOI: http://dx.doi.org/10.14392/asaa.2016090203

- Artigo recebido em 24/08/2015 e aprovado em 08/09/2016.
} 


\section{INTRODUCTION}

$\mathrm{n}$ recent years there has been increased interest in the difference between the figures disclosed

in the accounting books and those reported for tax purposes (book-tax differences, or BTDs) and their relationship with tax planning aggressiveness and earnings persistence. However, despite the widespread research on the interplay of these themes, there are still gaps in knowledge, especially regarding emerging countries such as Brazil (Ferreira et al., 2012).

The differences between the numbers reported in the tax ledgers and accounting books arise from the differences between tax legislation and accounting standards (Formigoni et al., 2009), especially regarding the treatment of accruals. These differences tend to be greater with more aggressive tax planning.

Companies with large BTDs can present earnings that are less persistent than their counterpart firms with small BTDs. Besides this, BTDs can be informative regarding management of accruals because there is less discretion in this respect in applying tax rules (Hanlon, 2005). Therefore, the analysis of BTDs can point to a tradeoff situation due to the effort to reduce the tax burden, causing changes in the persistence of earnings.

Further according to Hanlon (2005), the empirical evidence is coherent with the interpretation of investors that a large positive BTD is a "red flag", because this inevitably means less earnings persistence, causing reduced investor expectations. Lev \& Nissin. (2004) and Hanlon (2005) suggest that the tax figures contained accounting reports provide information on the persistence of earnings.

Therefore, an interpretation has been developed of this association according to which the information available in temporary BTDs about the persistence of earnings and accruals is incremental for the magnitude of accruals (Hanlon, 2005). Large BTDs are a sign of growth of discretionary accruals, so firms with large positive BTDs should show less persistent earnings and accruals (Xie, 2001). According to Hanlon (2005), the presence of accruals makes earnings less persistent, since at some future point the accruals will have to be reversed. According to Dechow et al. (2010), the persistence of earnings is relevant for estimates of the equity value of firms, since it is a consistent measure of the quality of earnings.

Despite the relevance of this subject, to the best of our knowledge, little is known about connection between BTDs and earnings persistence in the Brazilian market. A particular aspect of interest in Brazil is the recent convergence of accounting standards to International Financial Reporting Standards (IFRS). Therefore, this article investigates the following research question: Is there a relationship in Brazil between extreme temporary positive BTDs due to aggressive tax planning and earnings persistence, before and after the adoption of IFRS?

The justification for this study is based on the relevance of earnings persistence of Brazilian firms, because the more persistent earnings are, the easier it is to estimate future results based on past ones, in the scenario of tax planning in recent years.

Frankel \& Litov (2009) observed that earnings become less persistent due to the effects of economic shocks and problems in determining accounting income. According to Hanlon (2005), some companies show less persistent earnings and accruals in their financial reports due to large positive BTDs. Tang (2007) states that: 
...book-tax differences (BTD) [are] a useful measure of earnings management (EM) and tax mana gement (TM) after accounting for the mechanical differences due to the divergent reporting rules for book and tax purposes.

Further according to Tang (2006), BTDs indicate the quality of earnings because they identify opportunistic behavior to distort financial reports. Other studies have found that the information assimilated in BTDs associated with the quality of earnings affects the market's response to current and expected future profits (Tang, 2006).

The results found in this study point to the existence of a relationship among BTDs, persistence of earnings and accruals and aggressive tax planning under international accounting standards. Previous studies have pointed to BTDs as an indicator of more persistent earnings before the adoption of IFRS, but the results found here oppose those findings.

\section{THEORETICAL FRAMEWORK}

\subsection{BOOK-TAX DIFFERENCES - BTD}

Previous studies have indicated there are great difficulties in finding information on differences between tax and accounting books (book-tax differences, or BTDs), since firms in general do not disclose their tax data (Hanlon, 2005). According to Formigoni et al. (2009), there are two BTD categories, permanent and temporary differences:

Permanent differences occur when determined revenues or expenses are recognized in the accounts, but do not have tax effects. Temporary differences happen when both the tax and accounting systems recognize the same amount of revenue or expense, but diverge regarding the moment of this recognition.

For Drake (2013), permanent differences arise from differences between accounting and tax reports when the revenue or expense items are measured in one report but not in the other. In contrast, temporary differences only involve differences in the timing of recognition of revenue and/or expense items in the two reports. Likewise, Comprix et al. (2011) indicates that permanent differences occur when accounting and tax rules differ with respect to recognition of revenue and expense items, while temporary differences happen when the period of recognizing revenue and/or expense items differs.

Temporary differences can be positive or negative. Positive temporary differences arise when the accounting income is higher than the taxable income, while negative temporary differences occur when the accounting income is lower than the taxable income (Hanlon, 2005). According to Graham et al. (2012), temporary BTDs cause a difference between tax and accounting numbers in future periods. Therefore, when an asset is recovered or a liability settled, there will be differences between the bases for tax and accounting calculations.

Book-tax differences arising from the distinction between accounting and tax rules can also be classified as nondiscretionary, or normal (NBTDs), and discretionary, or abnormal (ABTDs). The former 
occur when the differences between tax and accounting rules do not allow any leeway for choice in application, while the latter arise when managers have discretion regarding either the figures themselves or the timing of recognizing revenue and expense items (deferral). Abnormal book-tax differences are associated with earnings management and/or tax planning (Formigoni et al., 2009; Blaylock et al., 2012).

\subsubsection{BTDs and Earnings Management}

There has been a good deal of investigation of BTDs as an indicator of earnings management (Hanlon, 2005; Seidman, 2010). Earnings management occurs when managers make discretionary decisions on the numbers disclosed in the financial statements or the structure of these statements for the purpose of altering the perception of shareholders and other interested parties about the company's reality (e.g., meeting analysts' forecasts) or to attain results required by contracts linked to financial results (e.g., ratios required by loan covenants) (Schipper, 1989; Healy \& Wahlen., 1999; Martinez, 2013).

For Badertscher et al. (2009), earnings management happens through the impact of tax and nontax factors on managers' choices regarding the disclosure of results. Some authors, such as Martinez (2013) and Santos et al. (2011), have also defined earnings management as occurring not only through managerial choices that impact the financial statements, but also by decisions that affect operating expenses. One of the ways that earnings management occurs is by choices regarding accruals (Santos et al., 2011). As pointed out by Martinez (2008), accruals are accounts in the balance sheet that represent liabilities and non-cash-based assets, among them accounts payable, accounts receivable, goodwill, future tax liabilities and future interest expenses. Accruals can be measured, in general, through the difference between net income and net operating cash flow.

Just as BTDs, accruals can be discretionary and nondiscretionary. According to Martinez (2008), the former are used to manage the accounting results while the latter are required according to the reality of the business. Discretionary accruals are subdivided into current accruals and non-current accruals. Both current and non-current accruals can be positive or negative, and when they are discretionary, they indicate whether the earnings have been managed upward or downward, respectively.

Positive current accruals increase profits without a necessary movement in the cash and cash equivalents account, such as immediate booking of the profits from installment sales. Negative current accruals reduce profits without movement of the cash and cash equivalents, such as provision for short-term labor contingencies (Martinez, 2008). The same differentiation applies to positive and negative non-current accruals. An example of the former happens with reversal of impairment, while an example of the latter happens with depreciation of fixed assets (Martinez, 2008).

Discretionary accruals are included in the accounting, or book, income but are often excluded from the taxable income, reducing the quality of earnings (Graham et al., 2012). Discretionary accruals are positively associated with future profitability (Xie, 2001). Accruals in general, when properly used, should better reflect the underlying soundness of the company, such as to smooth out transitory shocks to cash flow (Dechow, 1994; Dechow \& Weile, 2006).

Cash flow is considered a better indicator of companies' financial performance than net income, since cash flow is subject to less distortion based on different accounting practices (Dechow, 1994). Corporations did not have to disclose a cash flow statement in Brazil before the enactment of Law $11,638 / 2007$, which among other measures required adoption of IFRS by publicly traded corporations as of 2009. Because of this, accruals were estimated from the balance sheet, by measuring the variation of current assets, variation of cash and cash equivalents, variation of current liabilities, variation 
of short-term loans and financing, the amount of depreciation and amortization expenses and the amount of total assets (Martinez, 2013).

\subsubsection{BTDs and Tax Planning}

Discretionary book-tax differences can also arise from a tax planning strategy that attempts to defer (delay) payment of taxes for as long as possible to diminish the net present value of taxes paid. This strategy leads to an increase in deferred tax expense but does not necessarily result in accruals that are reversed in future years (Blaylock et al., 2012).

As suggested by Wilson (2009), large positive temporary BTDs signal aggressive tax planning. Hanlon \& Heitzman (2010) define aggressive tax planning (or tax avoidance) as "the reduction of explicit taxes". In theory, compliance with tax obligations is determined by tax rates, the likelihood of detection and severity of punishment for illegal practices and risk aversion.

Explicit taxes are those paid directly to the tax authorities, while implicit taxes are those paid indirectly, in the form of lower rates of pre-tax returns on incentivized investments (Shackelford \& Shevlin, 2001; Scholes et al., 2008, p. 2). This occurs, for example, if an investment is treated favorably for tax purposes and thus attracts more investors, reducing the rate of return due to heightened competition. In Brazil, an example of this mechanism is the tax incentives granted to manufacturing companies located in the Manaus Free Trade Zone.

Shackelford \& Shevlin (2001) indicate that effective tax planning does not only mean minimizing taxes, which is often the implicit objective when researchers study the effective tax rate calculated from the financial statements. Effective tax planning, according to the authors, has the objective of maximizing the after-tax rate of return while tax minimization aims to lower taxes.

Effective tax planning can be undermined by the personal interests of managers, part of the agency problem between principals (owners) and agents (managers). To reduce the chance for this type of problem, it is important for shareholders to structure incentives so that managers make efficient tax decisions (Hanlon et al., 2010).

The aspiration to reduce taxes can lead to problems between stockholders and "well-informed and opportunistic" managers. However, tax aspects and considerations of transaction costs related to information have contradictory implications in an efficient organization. Sometimes tax considerations are more important, while at other times informational considerations are more important. However, both factors are relevant, so there are always tradeoffs that must be observed. Due to the existence of these tradeoffs, efficient tax planning is often very different from just reducing the tax bite (Scholes et al., 2008).

\subsubsection{BTDs and Deferred Tax Expenses}

Discretionary book-tax differences can also arise from decisions on deferral of tax expenses in the absence of tax planning and earnings management, due to normal differences in the treatment of revenues and expenses for accounting and tax purposes (Scholes et al., 2008, p. 39; Blaylock et al., 2012). Normal temporary differences can arise, for example, from choices on depreciation of assets and provisions for doubtful debts, among many others that can be used for earnings management (Blaylock et al., 2012). 


\subsection{PERSISTENCE OF EARNINGS}

Earnings persistence is measured to serve as a proxy of earnings quality (Dechow et al., 2010). Therefore, those authors have the following comment on earnings quality:

Higher quality earnings provide more information about the features of a firm's financial performance that are relevant to a specific decision made by a specific decision-maker.

The theory of earnings persistence focuses on the utility of earnings reports to investors. The idea is that more persistent (less volatile) earnings are more useful to investors in making decisions on the firm's present equity value and future prospects. The main determinant of earnings persistence is one of the components of profits, namely accruals.

The persistence of earnings is affected by additions and reductions of assets. Dechow et al. (2010) found that extreme positive accruals indicate that firms are increasing the value of their assets, while extreme negative accruals indicate they are reducing the value of their assets.

Earnings are composed of accruals and cash flows. Sloan (1996) found evidence that earnings composed of accruals are less persistent than those composed of cash flows, because cash flows better represent the financial performance, the most relevant information for making investment decisions (Dechow, 1994; Dechow et al., 2010). According to Lev \& Nissin (2004), earnings can be affected by the magnitude of BTDs, so the ratio of taxable income to accounting income is a measure of the quality of earnings and hence contains incremental information about accruals and cash flows.

Earnings also play a role for evaluation if managers use this information. In this respect, persistent past earnings can serve as a substitute for prediction of future cash flows, and hence can be used as a starting point for predicting future profits (Frankel \& Litov, 2009).

Firms with more persistent earnings have more"sustainable" profits, as put by Dechow et al. (2010), thus serving as a rough yardstick of the expected cash flow to evaluate equity value. However, the authors also indicate that persistence depends both on the firm's performance and accounting system.

\subsection{RESEARCH JUSTIFICATION AND HYPOTHESES}

Hanlon (2005) analyzed the causes of large BTDs and the relation with persistence of earnings and accruals and found that discretionary accruals are less persistent than nondiscretionary accruals. If high BTDs indicate discretionarity in the accruals process, then companies with large BTDs should present less persistent earnings and accruals (Xie, 2001). In line with these arguments, Hanlon (2005) pointed out that firms with large BTDs present less persistent earnings and accruals than do firms with small BTDs. However, if accruals for accounting purposes are not also obtained for tax purposes, differences in deferred taxes arise, increasing them, meaning higher BTDs, and this difference can only indicate an increase in accounting accruals (Blaylock et al., 2012).

Blaylock et al. (2012) tested whether large BTDs supply useful incremental information about the persistence of earnings, besides the information provided by accruals. Their analysis was similar to that of Weber (2009), who analyzed whether errors in analysts' forecasts are observable and if these errors are associated with taxable income and book income after controlling for accruals. He found that analysts' forecasts for future profits showed an optimistic bias, where the accounting income was greater than the taxable income, even after controlling for accruals.

Temporary BTDs have incremental descriptive capability about discretionary accruals, estimated by the model of Jones, to detect earnings management (Phillips et al., 2003; Blaylock et al., 2012). Based on 
the above observations, here I analyze if BTDs have incremental explanatory power for the persistence of earnings and accruals and whether this pattern changed from the period before to after the adoption of international financial reporting standards (IFRS) in Brazil, through the following set of hypotheses:

H1a: Temporary BTDs provide incremental information on the magnitude of accruals and persistence of earnings.

$\mathrm{H} 1 \mathrm{~b}$ : Temporary BTDs provide incremental information on the magnitude of accruals and the persistence of the components of earnings.

$\mathrm{H} 1 \mathrm{c}$ : Temporary BTDs provide incremental information on the magnitude of accruals and the persistence of earnings in the period before and after the adoption of IFRS.

Assuming that BTDs have better incremental explanatory power, I investigate why BTDs can indicate differences in the persistence of earnings and accruals (Blaylock et al., 2012). For this purpose, Hanlon (2005) created three BTD subsamples, called LPBTD (large positive book-tax differences), LNBTD (large negative book-tax differences) and SmallBTD (small book-tax differences, here just SBTD) and generated separate predictions for persistence of earnings and accruals for these subsamples. We expect LPBTDs to act to lower the quality of the results reported due to earnings management (Hanlon, 2005; Blaylock et al., 2012).

According to Phillips et al. (2003), deferred tax expenses are a better measure than accruals to detect earnings management, because managers generally have more discretion under generally accepted accounting principles than under tax rules. An example of this management in Brazil is depreciation expense, which allows companies to increase book income without increasing taxable income.

In line with these definitions, we conclude that deferred tax expenses are a proxy for discretionary accruals and a useful incremental indicator of earnings management, by allowing companies to avoid decline of profits (Phillips et al., 2003).

In light of this discussion, we formulated the second set of hypotheses:

H2a: For firm-years with large positive BTDs, the persistence of earnings is lower for the subsamples of firms that manage earnings more than for the rest of the sample.

$\mathrm{H} 2 \mathrm{~b}$ : For firm-years with large positive BTDs, the persistence of the accrual components of earnings is lower for the subsamples of firms that manage earnings more than for the rest of the sample.

According to Wilson (2009) and Lisowsky (2010), the use of tax shelters is positively associated with BTDs, so that aggressive tax planning is an important determinant of BTDs. Therefore, it can be assumed that many firms report increases in LPBTD as a result of a tax planning strategy involving deferral of earnings or acceleration of deductions (Blaylock et al., 2012).

In line with these arguments, one can expect that in cases of large positive BTDs, probably resulting from an aggressive tax planning strategy, these BTDs are not a useful signal of less persistent earnings. Therefore, we formulated the third set of hypotheses:

H3a: For firm-years with large positive BTDs, the persistence of earnings is greater for the subsamples of more aggressive tax planners than for the rest of the firms.

H3b: For firm-years with large positive BTDs, the persistence of the accrual components of earnings is greater for the subsamples of more aggressive tax planners than for the rest of the firms.

In summary, the hypotheses suggest greater persistence of earnings and accruals for firms with large positive book-tax differences. Furthermore, in cases where LPBTDs occur in function of aggressive tax planning, the persistence of earnings and accruals should be larger and in cases where LPBTDs 
occur in function of earnings management, the persistence of earnings and accruals should be less (Blaylock et al., 2012).

There can also be firms with LPBTDs that cannot be specifically attributed to aggressive tax planning or earnings management. For these firms, LPBTDs probably arise from a combination of tax planning, discretionary accruals and characteristics of the firms, i.e., normal BTDs. Companies can present large BTDs due to difference in the timing of recognizing revenues and expenses that are associated with the economic segment (e.g., firms subject to large seasonal variations in revenues and/or expenses) or the particular business model (Blaylock et al., 2012).Finally, LPBTDs can provide information on the subjectivity of the accruals process of the remaining firms, but not to the extent this occurs for firms for which the main source of LPBTDs is upward earnings management (Blaylock et al., 2012).

\section{METHODOLOGY}

\subsection{SAMPLE SELECTION}

The sample of firms analyzed here consists of all nonfinancial firms listed on the BM\&FBovespa between 2003 and 2012, because this interval straddles the mandatory adoption of IFRS in Brazil in 2009, allowing analysis of the situation before and after this change. This sample is composed of 727 firms. The data were obtained from the Economatica database. The study takes a quantitative approach, seeking to find the determinants of the phenomenon of interest by analyzing the relationships between the variables (Creswell, 2007, p. 161). We applied the model of Jones, because it enables controlling for nondiscretionary accruals, and from there indirectly estimating the value of discretionary accruals (Martinez, 2008).

I used pooled regression by ordinary least squares (OLS), followed by the White test, because this model allows detecting heteroskedasticity, which occurs when there are subpopulations with variances. I also applied panel data analysis with the Durbin-Watson statistic, which is used to measure the autocorrelation between each of the residuals and the residual corresponding to the immediately previous time period (Levine et al., 2012).

\subsection{SAMPLE COLLECTION}

BTD was estimated for each firm-year as (deferred tax expenses / 0.34) divided by average total assets (total assets at the start and end of the year divided by two). As a result, the sample was divided into quintiles, with the quintile with large positive BTDs called LPBTD (1454 observations), the quintile with large negative BTDs called LNBTD (1454 observations), and all the other observations were classified as small BTDs (SBTD, 4362 observations). The variables LPBTD, LNBTD and IFRS are dummy variables.

The variable LPBTD was estimated by assigning a value of 1 to the greatest positive quintile and 0 for the rest of the sample. - The variable LNBTD was estimated by assigning a value of 1 to the greatest negative quintile and 0 for the rest of the sample. - The variable IFRS was estimated by assigning a value of 0 for years until 2009 and 1 for other years.

The discretionary accruals were estimated using the Jones model. The "depreciation, amortization and depletion" account used to calculate accruals was listed in the statement of changes in financial position in the period from 2003 to 2007 and in the cash flow statement in the period from 2008 to 
2012. The data referring to the "cash and cash equivalents" account were only collected starting in 2010, because before this these data were not grouped like this. Instead, it was necessary to use the accounts "cash, short-term financial investments and working capital" and "short-term equity investments" for the period from 2003 to 2009.

$\mathrm{EBITt}+1$ was scaled by dividing pre-tax earnings for year $\mathrm{t}+1$ by the average of all previous years, while EBITt was scaled by dividing the pre-tax earnings in year $t$ by the average of the figures for years t and t-1. PTCFt (pre-tax cash flow) was defined by EBITt minus PTACC (pre-tax accruals), divided by the average total assets, while PTACC was defined by EBITt minus PTCFt..

The PLANNER group was estimated by the long-run ETR metric (The ETR metric was estimated by assigning a value of 1 to the lowest quartile and 0 to the others), which corresponds to the sum of income taxes for the previous three years divided by pre-tax earnings (EBIT) for the same period. According to Hanlon \& Heitzman (2010), long-run ETR is a suitable indicator of aggressive tax planning.

\section{ANALYSIS OF THE DATA}

\subsection{TEST OF EARNINGS PERSISTENCE}

The initial model for all the tests of earnings persistence was that proposed by Hanlon (2005, p. 145), as demonstrated below:

$\mathrm{PTBI}_{\mathrm{t}+1}=\mathrm{y}_{0}+\mathrm{y}_{1} \mathrm{PTBI}_{\mathrm{t} \varepsilon_{\mathrm{t}+1}}$

In this model, PTBI represents pre-tax book income, estimated for a future period, divided by the average total assets, and $\mathrm{y} 1$ is an estimate of future earnings from current earnings, used as a persistence parameter.

Blaylock et al. $(2012$, p. 98,100$)$ also tested other models proposed by Hanlon $(2005$, p. 145,146$)$, as follows:

$$
\begin{aligned}
& \text { PTBI }_{t+1}=y_{0}+y_{1} \text { LPBTD }_{t}+y_{2} \text { LNBTD }_{t}+y_{3} \text { PTBI }_{t}+y_{4} \text { PTBI }_{t} \times \text { LPBTD }_{t} \\
& +y_{5} \text { PTBI }_{t} \times \text { LNBTD }_{t}+\varepsilon t+1 \\
& \text { PTBI }_{t+1}=y_{0}+y_{1} \text { PTCF }_{t}+y_{2} \text { PTACC }_{{ }_{t t+1}}
\end{aligned}
$$

In these models, PTCF is pre-tax cash flow and PTACC is pre-tax accruals, both scaled by average total assets. The coefficients $y 1$ and y 2 of model (3) are estimates for the persistence of cash flows and accruals in future periods (Sloan, 1996; Xie, 2001; Hanlon, 2005). Models (2) and (4) are the bases of the earnings persistence tests carried out by Hanlon (2005).

$$
\begin{aligned}
& \text { PTBI }_{t+1}=y_{0}+y_{1} \text { LPBTD }_{t}+y_{2} \text { LNBTD }_{t}+y_{3} \text { PTCF }_{t}+y_{4} \text { PTACC }_{t}+y_{5} \text { PTCF }_{t} \times \text { LPBTD }_{t} \\
& +y_{6} \text { PTACC }_{t} \times \text { LPBTD }_{t}+y_{7} \text { PTCF }_{t} \times \text { LNBTD }_{t}+y_{8} \text { PTACC }_{t} \times \text { LNBTD }_{t}+{ }_{\varepsilon t+1}
\end{aligned}
$$

The tables below report the descriptive statistics of the models: 
Table 1: Panel A: Small Positive BTD

\begin{tabular}{|c|c|c|c|c|c|}
\hline Variable & Mean & \multicolumn{1}{l|}{ Median } & Minimum & \multicolumn{1}{l|}{ Maximum } & Standard Deviation \\
\hline BTDt & 0.000 & 0.000 & 0.000 & 0.000 & 0.000 \\
\hline EBITt+1 & -6.089 & 0.000 & -19415.50 & 3.821 & 299.842 \\
\hline EBITt & -7.188 & 0.000 & -27691.50 & 763.500 & 421.084 \\
\hline PTCFt & -0.510 & 0.000 & -1815.020 & 0.995 & 27.520 \\
\hline PTACCt & -6.679 & 0.000 & -27690.34 & 762.505 & 419.613 \\
\hline Average Assetst & 2.819 .150 .35 & 0.00 & 0.00 & 627.344 .495 .00 & 25.147 .703 .83 \\
\hline ABSACCt & -1544.995 & 0.000 & -686004.6 & 8512.714 & 10389.113 \\
\hline ETRt & 0.051 & 0.000 & -56.395 & 27.291 & 1.164 \\
\hline
\end{tabular}

Panel B: Large Negative BTD

\begin{tabular}{|c|c|c|c|c|c|}
\hline Variable & Mean & \multicolumn{1}{l|}{ Median } & Minimum & Maximum & Standard Deviation \\
\hline BTDt & -0.034 & -0.013 & -1.036 & 0.000 & 0.072 \\
\hline EBITt+1 & 0.016 & 0.032 & -13.429 & 2.064 & 0.485 \\
\hline EBITt & -0.043 & 0.029 & -45.181 & 1.852 & 1.657 \\
\hline PTCFt & -0.001 & 0.000 & -0.819 & 0.000 & 0.023 \\
\hline PTACCt & -0.042 & 0.029 & -45.178 & 1.852 & 1.642 \\
\hline Average Assetst & 11.396 .163 .22 & 1.505 .285 .75 & 0.00 & 1.051 .415 .271 .50 & 63.293 .723 .28 \\
\hline ABSACCt & -44.682 & -0.021 & -69772.000 & 4733.000 & 1834.075 \\
\hline ETRt & 0.016 & 0.240 & -251.014 & 34.516 & 6.779 \\
\hline
\end{tabular}

Panel C: Large Positive BTD

\begin{tabular}{|c|c|c|c|c|c|}
\hline Variable & Mean & \multicolumn{1}{l|}{ Median } & Minimum & Maximum & Standard Deviation \\
\hline BTDt & 0.025 & 0.010 & 0.000 & 0.644 & 0.046 \\
\hline EBITt+1 & -0.023 & 0.036 & -20.500 & 0.647 & 0.852 \\
\hline EBITt & 0.789 & 0.042 & -89.649 & 1290.422 & 33.934 \\
\hline PTCFt & 0.020 & 0.000 & -11.143 & 0.002 & 0.414 \\
\hline PTACCt & 0.809 & 0.042 & -88.643 & 1290.420 & 33.922 \\
\hline Average Assetst & 7.810 .419 .93 & 974.764 .50 & 0.00 & 884.821 .431 .00 & 44.647 .411 .17 \\
\hline ABSACCt & 4.848 & -0.001 & -9.000 & 2957.000 & 104.106 \\
\hline ETRt & 0.108 & 0.135 & -37.353 & 7.694 & 1.144 \\
\hline
\end{tabular}

Presumably, firms in the LPBTD and LNBTD groups are characterized by less persistent earnings and accruals than those in the SBTD group. For the purpose of analyzing whether BTDs are driven by differences in the persistence of accruals, the models were expanded (Hanlon, 2005; Blaylock et al., 2012). The models to test hypotheses $\mathrm{H} 1 \mathrm{a}, \mathrm{H} 1 \mathrm{~b}$ and $\mathrm{H} 1 \mathrm{c}$, respectively, are shown below.

$$
\begin{gathered}
\text { EBIT }_{t+1}=y_{0}+y_{1} \text { LPBTDt }_{+} y_{2} \text { LNBTD }_{t}+y_{3} \text { ABSACC }_{t}+y_{4} \text { EBIT }_{t}+y_{5} \text { EBIT }_{t} \times \text { LPBTD }_{t}+y_{6} \text { EBIT }_{t} x \\
\text { LNBTDt }+y_{7} \text { EBITt } \times A B S A C C t+{ }_{t t+1}
\end{gathered}
$$

$$
\begin{aligned}
& \text { EBIT }_{t+1}=y_{0}+y_{1} \text { LPBTD }_{t}+y_{2} \text { LNBTD }_{t}+y_{3} \text { ABSACC }_{t}+y_{4} \text { PTCF }_{t}+y_{5} \text { PTACC }_{t}+y_{6} \text { PTCF }_{t} x \text { LPBTD }_{t}+ \\
& y_{7} \text { PTACC }_{t} \times \text { LPBTD }_{t}+y_{8} \text { PTCF }_{t} \times \text { LNBTD }_{t}+y_{9} \text { PTACC }_{t} \times \text { LNBTD }_{t}+y_{10} \text { PTCF }_{t} \times \text { ABSACC }_{t}+ \\
& \mathrm{y}_{11} \text { PTACC }_{\mathrm{t}} \times \text { ABSACC }_{\mathrm{t}}+{ }_{\varepsilon t+1} \\
& \text { EBIT }_{t+1}=y_{0}+y_{1} \text { LPBTD }_{t}+y_{2} \text { LNBTD }_{t}+y_{3} \text { ABSACC }_{t}+y_{4} \text { EBIT }_{t}+y_{5} \text { IFRS }_{t}+y_{6} \text { EBIT }_{t} x \text { LPBTD }_{t}+
\end{aligned}
$$




$$
\begin{aligned}
& y_{7} \text { EBIT }_{t} \times \text { LNBTD }_{t}+y_{8} \text { EBIT }_{t} \times \text { ABSACC }_{t}+y_{9} \text { EBIT }_{t} \times \text { LPBTD }_{t} \times \text { IFRS }_{t}+y_{10} \text { EBIT }_{t} \times \\
& \text { LNBTD }_{t} \times \text { IFRS }_{t}+y_{11} \text { EBIT }_{t} \times \text { ABSACC }_{t} \times \text { IFRS }_{t}+_{c t+1}
\end{aligned}
$$

In these models, EBIT is pre-tax earnings, LPBTD denotes the group of firms with large positive BTDs, LNBTD represents the firms with large negative BTDs, ABSACC is the absolute value of pre-tax accruals, PTCF is pre-tax cash flow, PTACC is pre-tax accruals (Blaylock et al., 2012) and IFRS indicates the adoption of international accounting standards.

We used the absolute value of accruals because Sloan (1996) and Dechow et al. (2010) showed that what affects the persistence of earnings and accruals is the magnitude of accruals, whether or not they are on the asset or liability side. Furthermore, all the implications on the persistence of earnings and accruals will be the same when using the absolute value of discretionary accruals instead of the absolute value of accruals in general (Blaylock et al., 2012).

Table 2 presents the results of the estimation of the three models. In panels $A$ and $B$, the coefficient of EBITt indicates significance of the predictions. The LPBTDs and LNBTDs provide incremental useful information on the persistence of earnings. In panels $C$ and $D$, the results provide information for the persistence of cash flows and accruals. After controlling for accruals, the persistence of accruals is lower for the firms in the LNBTDs and LPBTDs, indicating that BTDs can supply incremental information about the persistence of accruals. Finally, in panel $E$ and $F$, the coefficient of IFRS indicates the persistence before and after adopting international accounting standards in Brazil. The results appear to provide information about the persistence of earnings and accruals after the adoption of international accounting rules.

Table 2: Do large temporary BTDs provide incremental information about accruals? Panel A: OLS regression for future pre-tax earnings over current pre-tax earnings, controlling for the absolute

\begin{tabular}{|c|c|c|c|c|c|c|}
\hline \multirow{2}{*}{$\begin{array}{c}\text { Variable } \\
(\mathrm{EBITt}+1)\end{array}$} & \multirow{2}{*}{ Coefficients } & \multirow{2}{*}{$\begin{array}{l}\text { Robust } \\
\text { Standard } \\
\text { Error }\end{array}$} & \multirow{2}{*}{ t-statistic } & \multirow{2}{*}{$\mathrm{p}$-value } & \multicolumn{2}{|c|}{ 95\% Confidence Interval } \\
\hline & & & & & Minimum & Maximum \\
\hline LPBTD & 1.275 & 0.889 & 1.43 & 0.152 & -0.468 & 3.019 \\
\hline LNBTD & 1.322 & 0.889 & 1.49 & 0.137 & -0.420 & 3.065 \\
\hline ABSACC & 2.00 & 1.30 & 1.54 & 0.124 & -5.47 & 4.55 \\
\hline EBITt & 0.700 & 0.000 & 889.47 & 0.000 & 0.699 & 0.702 \\
\hline EBITt x LPBTD & -0.699 & 0.001 & -420.47 & 0.000 & -0.703 & -0.696 \\
\hline EBITt $x$ LNBTD & -0.517 & 0.105 & -4.92 & 0.000 & -0.723 & -0.311 \\
\hline EBITt x ABSACC & 0.000 & 9.93 & -532.04 & 0.000 & 0.000 & 0.000 \\
\hline _cons & -1.298 & 0.889 & -1.46 & 0.144 & -3.04 & 0.444 \\
\hline R-squared & 0.9617 & & & & & \\
\hline F-statistic & 0.000 & & & & & \\
\hline
\end{tabular}
value of pre-tax accruals $(n=7,270)$.

Panel B: Panel regression with fixed effects for future pre-tax earnings over current pre-tax earnings, controlling for the absolute value of pre-tax accruals $(n=7,270)$.

\begin{tabular}{|c|c|c|c|c|c|c|}
\hline $\begin{array}{c}\text { Variable } \\
\text { (EBITt+1) }\end{array}$ & Coefficients & $\begin{array}{c}\text { Standard } \\
\text { Error }\end{array}$ & $T$ & \multicolumn{2}{|c|}{$p$-value } & \multicolumn{2}{|c|}{$95 \%$ Confidence Interval } \\
\hline LPBTD & 0.851 & 1.652 & 0.52 & 0.606 & -2.388 & 4.092 \\
\hline LNBTD & 1.854 & 1.754 & 1.06 & 0.290 & -1.584 & 5.293 \\
\hline ABSACC & 0.000 & 0.000 & 8.56 & 0.000 & 0.000 & 0.000 \\
\hline EBITt & 0.701 & 0.001 & 405.26 & 0.000 & 0.697 & 0.704 \\
\hline EBITt x LPBTD & -0.701 & 0.036 & -19.05 & 0.000 & -0.773 & -0.629 \\
\hline EBITt x LNBTD & -0.691 & 0.755 & -0.91 & 0.36 & -2.172 & 0.789 \\
\hline EBITt x ABSACC & 0.000 & 2.35 & -21.97 & 0.000 & 0.000 & 0.000 \\
\hline _cons & -1.379 & 0.781 & -1.77 & 0.078 & -2.910 & 0.152 \\
\hline
\end{tabular}




\begin{tabular}{|c|c|l|l|l|l|l|}
\hline R-squared & 0.9613 & & & & & \\
\hline F-statistic & 0.000 & & & & & \\
\hline
\end{tabular}

Panel C: OLS regression for future pre-tax earnings over the components of current pre-tax earnings, controlling for the absolute value of pre-tax accruals $(n=7,270)$.

\begin{tabular}{|c|c|c|c|c|c|c|}
\hline $\begin{array}{c}\text { Variable } \\
\text { (EBITt+1) }\end{array}$ & Coefficients & \multirow{2}{*}{$\begin{array}{c}\text { Robust } \\
\text { Standard } \\
\text { Error }\end{array}$} & t-statistic & p-value & \multicolumn{2}{|c|}{$95 \%$ Confidence Interval } \\
\cline { 5 - 7 } & & 1.652 & 0.52 & 0.606 & -2.388 & 4.092 \\
\hline LPBTD & 0.851 & 1.754 & 1.06 & 0.290 & -1.584 & 5.293 \\
\hline LNBTD & 1.854 & 0.000 & 8.56 & 0.000 & 0.000 & 0.000 \\
\hline ABSACC & 0.000 & 0.001 & 405.26 & 0.000 & 0.697 & 0.704 \\
\hline EBITt & 0.701 & 0.036 & -19.05 & 0.000 & -0.773 & -0.629 \\
\hline EBITt x LPBTD & -0.701 & 0.755 & -0.91 & 0.36 & -2.172 & 0.789 \\
\hline EBITt x LNBTD & -0.691 & 2.35 & -21.97 & 0.000 & 0.000 & 0.000 \\
\hline EBITt x ABSACC & 0.000 & 0.781 & -1.77 & 0.078 & -2.910 & 0.152 \\
\hline _cons & -1.379 & & & & & \\
\hline R-squared & 0.9613 & & & & & \\
\hline F-statistic & 0.000 & & & & & \\
\hline
\end{tabular}

Panel D: Panel regression with fixed effects for future pre-tax earnings over the components of current pre-tax earnings, controlling for the absolute value of pre-tax accruals $(n=7,270)$.

\begin{tabular}{|c|c|c|c|c|c|c|}
\hline \multirow{2}{*}{$\begin{array}{c}\text { Variable } \\
(\mathrm{EBITt}+1)\end{array}$} & \multirow{2}{*}{ Coefficients } & \multirow{2}{*}{$\begin{array}{l}\text { Standard } \\
\text { Error }\end{array}$} & \multirow{2}{*}{$\mathrm{T}$} & \multirow{2}{*}{$\mathrm{p}$-value } & \multicolumn{2}{|c|}{ 95\% Confidence Interval } \\
\hline & & & & & Minimum & Maximum \\
\hline LPBTD & 0.881 & 1.656 & 0.53 & 0.595 & -2.366 & 4.129 \\
\hline LNBTD & 1.867 & 1.756 & 1.06 & 0.288 & -1.575 & 5.309 \\
\hline ABSACC & 0.000 & 0.001 & 0.41 & 0.680 & -0.002 & 0.003 \\
\hline PTCFt & 0.808 & 0.613 & 1.32 & 0.188 & -0.394 & 2.012 \\
\hline PTACCt & 0.701 & 0.004 & 152.58 & 0.000 & 0.692 & 0.710 \\
\hline PTCFt $x$ LPBTD & 0.269 & 3.018 & 0.09 & 0.929 & -5.648 & 6.187 \\
\hline PTACCt $x$ LPBTD & -0.701 & 0.037 & -18.95 & 0.000 & -0.774 & -0.629 \\
\hline PTCFt $x$ LNBTD & 9.849 & 73.228 & 0.13 & 0.893 & -133.7024 & 153.401 \\
\hline PTACCt $x$ LNBTD & -0.780 & 1.002 & -0.78 & 0.436 & -2.746 & 1.185 \\
\hline PTCFt $x$ ABSACC & 0.000 & 0.001 & -0.06 & 0.951 & -0.002 & 0.002 \\
\hline PTACCt $\times$ ABSACC & 0.000 & 0.003 & -0.01 & 0.989 & -0.006 & 0.006 \\
\hline _cons & -1.376 & 0.783 & -1.76 & 0.079 & -2.911 & 0.158 \\
\hline R-squared & 0.9613 & & & & & \\
\hline F-statistic & 0.000 & & & & & \\
\hline
\end{tabular}

Panel E: OLS regression for future pre-tax earnings over current pre-tax earnings, controlling for the absolute value of pre-tax accruals, before and after adoption of international accounting standards $(n=7,270)$.

\begin{tabular}{|c|c|c|c|c|c|c|}
\hline \multirow{2}{*}{$\begin{array}{c}\text { Variable } \\
(\mathrm{EBITt}+1)\end{array}$} & \multirow{2}{*}{ Coefficients } & \multirow{2}{*}{$\begin{array}{l}\text { Robust } \\
\text { Standard } \\
\text { Error }\end{array}$} & \multirow{2}{*}{ t-statistic } & \multirow{2}{*}{$\mathrm{p}$-value } & \multicolumn{2}{|c|}{ 95\% Confidence Interval } \\
\hline & & & & & Minimum & Maximum \\
\hline LPBTD & 0.878 & 0.619 & 1.42 & 0.156 & -0.334 & 2.09 \\
\hline LNBTD & 1.224 & 0.830 & 1.47 & 0.140 & -0.403 & 2.851 \\
\hline ABSACC & 2.62 & 2.44 & 1.07 & 0.284 & -2.17 & 7.41 \\
\hline EBITt & 0.700 & 0.010 & 64.29 & 0.000 & 0.678 & 0.721 \\
\hline IFRS & 1.070 & 0.781 & 1.37 & 0.171 & -0.461 & 2.602 \\
\hline EBITt x LPBTD & 1.943 & 1.485 & 1.31 & 0.191 & -0.967 & 4.855 \\
\hline EBITt x LNBTD & -0.537 & 0.104 & -5.12 & 0.000 & -0.742 & -0.331 \\
\hline EBITt x ABSACC & 0.000 & 0.008 & 0.02 & 0.984 & -0.0163 & 0.0166 \\
\hline $\begin{array}{c}\text { EBITt } x \text { LPBTD } \\
\text { x IFRS }\end{array}$ & -2.643 & 1.486 & -1.78 & 0.075 & -5.558 & 0.270 \\
\hline $\begin{array}{c}\text { EBITt x } x \text { LNBTD } \\
\text { x IFRS }\end{array}$ & 0.624 & 0.307 & 2.03 & 0.043 & 0.020 & 1.227 \\
\hline $\begin{array}{c}\text { EBITt } x \text { ABSACC } \\
x \text { IFRS }\end{array}$ & 0.000 & 0.008 & -0.03 & 0.979 & -0.0167 & 0.0163 \\
\hline
\end{tabular}




\begin{tabular}{|c|c|c|c|c|c|c|}
\hline _cons & -1.642 & 1.138 & -1.44 & 0.149 & -3.874 & 0.589 \\
\hline R-squared & 0.9617 & & & & & \\
\hline F-statistic & 0.000 & & & & & \\
\hline
\end{tabular}

Panel F: Panel regression with fixed effects for future pre-tax earnings over current pre-tax earnings, controlling for the absolute value of pre-tax accruals, before and after adoption of international accounting standards $(n=$

7,270).

\begin{tabular}{|c|c|c|c|c|c|c|}
\hline $\begin{array}{l}\text { Variable } \\
(\mathrm{EBITt}+1)\end{array}$ & Coefficients & $\begin{array}{c}\text { Standard } \\
\text { Error }\end{array}$ & $\mathrm{T}$ & $\mathrm{p}$-value & \multicolumn{2}{|c|}{ 95\% Confidence Interval } \\
\hline LPBTD & 0.188 & 1.758 & 0.11 & 0.915 & -3.258 & 3.634 \\
\hline LNBTD & 1.627 & 1.773 & 0.92 & 0.359 & -1.849 & 5.104 \\
\hline ABSACC & 0.000 & 0.000 & 8.54 & 0.000 & 0.000 & 0.000 \\
\hline EBITt & 0.712 & 0.0129 & 54.79 & 0.000 & 0.686 & 0.737 \\
\hline IFRS & 1.324 & 1.147 & 1.16 & 0.248 & -0.923 & 3.573 \\
\hline EBITt $x$ LPBTD & 2.756 & 14.313 & 0.19 & 0.847 & -25.303 & 30.816 \\
\hline EBITt $x$ LNBTD & -0.700 & 0.760 & -0.92 & 0.357 & -2.191 & 0.790 \\
\hline EBITt $\times$ ABSACC & -0.008 & 0.0103 & -0.84 & 0.399 & -0.0290 & 0.0115 \\
\hline $\begin{array}{c}\text { EBITt } x \text { LPBTD } \\
x \text { IFRS }\end{array}$ & -3.468 & 14.313 & -0.24 & 0.809 & -31.527 & 24.590 \\
\hline $\begin{array}{c}\text { EBITt } x \text { LNBTD } \\
x \text { IFRS }\end{array}$ & -1.369 & 6.479 & -0.21 & 0.833 & -14.072 & 11.332 \\
\hline $\begin{array}{c}\text { EBITt } x \text { ABSACC } \\
x \text { IFRS }\end{array}$ & 0.008 & 0.010 & 0.84 & 0.402 & -0.0116 & 0.029 \\
\hline _cons & -1.742 & 0.842 & -2.07 & 0.039 & -3.394 & -0.090 \\
\hline R-squared & 0.9613 & & & & & \\
\hline F-statistic & 0.000 & & & & & \\
\hline
\end{tabular}

In all the models, the R-squared values indicate that the independent variables have power to explain the dependent variable (variation of pre-tax book income) of around $96 \%$. The F-value for significance of the models is within the confidence interval $(a=0.05)$, demonstrating statistical significance of the regressions, indicating a linear relation exists between the dependent variable and independent variables.

In panels $A$ and $B$, the $p$-value is lower than the cutoff level of significance, indicating rejection of $\mathrm{H} 0$. The multicollinearity tests verify whether or not the independent variables are mutually correlated. The data in these two tables indicate absence of multicollinearity. Besides this, the coefficients of the variables EBITt, EBITt x LPBTD, EBITt $x$ LNBTD and EBITt $x$ ABSACC are negative, indicating less persistent earnings in the presence of large positive BTDs and absolute accruals.

In panels $C$ and $D$, the $p$-value is lower than the significance level, again indicating rejection of the H0. Again, the tests show absence of multicollinearity, and the coefficients of the variables PTCFt $x$ LPBTD and PTACCt $x$ LPBTD are negative, indicating less persistence of the components of earnings in the presence of large positive BTDs and accruals.

Finally, in panels $E$ and $F$ the $p$-value is also below the significance level, indicating rejection of the $\mathrm{HO}$. The data evidence an absence of multicollinearity and the coefficients of the variables IFRS and EBITt $x$ LPBTD are positive, indicating more persistent pre-tax earnings before adoption of international accounting standards, while the coefficients of the variable EBITt $x$ LPBTD $x$ IFRS are negative, indicating less persistence of pre-tax earnings after adoption of those standards.

\subsection{PARTITIONING BOOK-TAX DIFFERENCES}

Having established that BTDs have incremental power to explain the variation in the persistence of earnings and accruals, this section presents the results of testing hypotheses $\mathrm{H} 2 \mathrm{a}, \mathrm{H} 2 \mathrm{~b}, \mathrm{H} 3 \mathrm{a}$ and $\mathrm{H} 3 \mathrm{~b}$, for 
the purpose of explaining why firms appear in the LPBTD group and why differences can be expected in the persistence of earnings and accruals (Blaylock et al., 2012).

These tests enable verifying the probability that BTDs are the result of earnings management or aggressive tax planning (tax sheltering), observed by the variable PLANNER (Blaylock et al., 2012). The models are tested only considering the PLANNER variable, because the aim is only to analyze the aggressive tax planning variable, not the variable corresponding to earnings management. To test hypotheses $\mathrm{H} 2 \mathrm{a}$ and $\mathrm{H} 3 \mathrm{a}$, I developed the following model:

$$
\mathrm{EBIT}_{\mathrm{t}+1}=\mathrm{y}_{0}+\mathrm{y}_{1} \text { PLANNER }_{\mathrm{t}}+\mathrm{y}_{2} \text { EBIT }_{\mathrm{t}}+\mathrm{y}_{3} \mathrm{EBIT}_{\mathrm{t}} \times \text { PLANNER }_{\mathrm{t}}+{ }_{\varepsilon t+1}
$$

Here the coefficient y2 represents the earnings persistence of firms with LPBTDs that are in the rest of the samples (those not classified as aggressive tax planners). For these firms, the LPBTDs are probably the result of some combination of aggressive tax planning, earnings management and firm-specific characteristics, so earnings persistence is expected for the LPBTD group. Hypothesis H3a predicts that $\bigotimes 3$ will be negative (Blaylock et al., 2012).

This model shows that LPBTDs resulting from earnings management indicate the existence of discretionary accruals. Nevertheless, if positive BTDs are mainly the result of tax planning, then the expectation is that the persistence of earnings is greater for this subset of companies (Blaylock et al., 2012).

According to Blaylock et al. (2012), hypotheses $\mathrm{H} 2 \mathrm{~b}$ and $\mathrm{H} 3 \mathrm{~b}$ predict differences in the persistence of accruals in the subsample of firms in the LPBTD group. To test the persistence of accruals in these subsamples, I formulated the following equation:

EBIT $_{\mathrm{t}+1}=\mathrm{y}_{0}+\mathrm{y}_{1}$ PLANNER $_{\mathrm{t}}+\mathrm{y}_{2}$ PTCF $_{\mathrm{t}}+\mathrm{y}_{3}$ PTCF $_{\mathrm{t}} \times$ PLANNER $_{\mathrm{t}}+\mathrm{y}_{4}$ PTACC $_{\mathrm{t}}+\mathrm{y}_{5}$ PTACC $_{\mathrm{t}} \times$ PLANNER $_{\mathrm{t}}+{ }_{\varepsilon t+1}$

Hypothesis $\mathrm{H} 3 \mathrm{~b}$ predicts that $\mathrm{y} 5$ will be negative. To test this hypothesis, we selected the firms in the PLANNER subsample and used the approach described below (Blaylock et al., 2012).

Table 3: Panel A: PLANNER in large positive BTDs

\begin{tabular}{|c|c|c|c|c|c|}
\hline Variable & Mean & Median & Minimum & Maximum & Standard Deviation \\
\hline BTDt & 0.025 & 0.010 & 0.000 & 0.644 & 0.046 \\
\hline EBITt+1 & -0.023 & 0.036 & -20.500 & 0.647 & 0.852 \\
\hline EBITt & 0.789 & 0.042 & -89.649 & 1290.422 & 33.934 \\
\hline PTCFt & -0.020 & 0.000 & -11.143 & 0.002 & 0.414 \\
\hline PTACCt & 0.809 & 0.042 & -88.643 & 1290.420 & 33.922 \\
\hline
\end{tabular}

Panel B: OLS regression for future pre-tax earnings over current pre-tax earnings with $\operatorname{LPBTD}(n=7,270)$.

\begin{tabular}{|c|c|c|c|c|c|c|}
\hline $\begin{array}{c}\text { Variable } \\
(\text { EBITt+1) }\end{array}$ & Coefficients & \multirow{2}{*}{$\begin{array}{c}\text { Robust } \\
\text { Standard } \\
\text { Error }\end{array}$} & t-statistic & p-value & \multicolumn{2}{|c|}{$95 \%$ Confidence Interval } \\
\cline { 5 - 7 } & & 2.046 & -1.02 & 0.307 & -6.100 & 1.921 \\
\hline PLANNER & -2.089 & 0.005 & 118.51 & 0.000 & 0.684 & 0.707 \\
\hline EBITt & 0.696 & 0.015 & -44.94 & 0.000 & -0.706 & -0.647 \\
\hline EBITt x PLANNER & -0.677 & 0.317 & -0.81 & 0.418 & -0.878 & 0.364 \\
\hline _cons & -0.256 & & & & & \\
\hline R-squared & 0.9576 & & & & & \\
\hline F-statistic & 0.000 & & & & & \\
\hline
\end{tabular}


Panel C: Panel regression with fixed effects for future pre-tax earnings over current pre-tax earnings with LPBTD

$(n=7,270)$

\begin{tabular}{|c|c|c|c|c|c|c|}
\hline \multirow{3}{*}{ 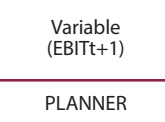 } & \multirow{3}{*}{$\begin{array}{c}\text { Coefficients } \\
-2.089\end{array}$} & \multirow{3}{*}{$\begin{array}{c}\begin{array}{c}\text { Standard } \\
\text { Error }\end{array} \\
2.046\end{array}$} & \multirow{3}{*}{$\begin{array}{c}\mathrm{T} \\
-1.02\end{array}$} & \multirow{3}{*}{$\begin{array}{c}p \text {-value } \\
0.307\end{array}$} & \multirow{2}{*}{\multicolumn{2}{|c|}{$\begin{array}{c}95 \% \text { Confidence } \\
\text { Interval }\end{array}$}} \\
\hline & & & & & & \\
\hline & & & & & -6.100 & 1.921 \\
\hline EBITt & 0.701 & 0.001 & 383.69 & 0.000 & 0.697 & 0.705 \\
\hline EBITt $\times$ PLANNER & -0.687 & 0.059 & -11.62 & 0.000 & -0.803 & -0.571 \\
\hline _cons & -0.374 & 0.667 & -0.56 & 0.575 & -1.681 & 0.933 \\
\hline R-squared & 0.9576 & & & & & \\
\hline F-statistic & 0.000 & & & & & \\
\hline
\end{tabular}

Panel D: OLS regression for future pre-tax earnings over the components of current pre-tax earnings with LPBTD $(n=7,270)$.

\begin{tabular}{|c|c|c|c|c|c|c|}
\hline \multirow{2}{*}{$\begin{array}{c}\text { Variable } \\
\text { (EBITt+1) }\end{array}$} & Coefficients & $\begin{array}{c}\text { Robust } \\
\text { Standard } \\
\text { Error }\end{array}$ & t-statistic & p-value & \multicolumn{2}{|c|}{$\begin{array}{c}\text { Interval } \\
\text { Minimum } \\
\text { Maximum }\end{array}$} \\
\hline PLANNER & -1.786 & 2.046 & -0.87 & 0.383 & -5.798 & 2.224 \\
\hline PTCFt & 0.114 & 0.002 & 38.99 & 0.000 & 0.108 & 0.120 \\
\hline PTCFt x PLANNER & 1.523 & 0.287 & 5.30 & 0.000 & 0.960 & 2.086 \\
\hline PTACCt & 0.699 & 0.002 & 333.83 & 0.000 & 0.695 & 0.703 \\
\hline PTACCtx PLANNER & -0.688 & 0.009 & -70.48 & 0.000 & -0.708 & -0.669 \\
\hline _cons & -0.469 & 0.264 & -1.78 & 0.076 & -0.986 & 0.048 \\
\hline R-squared & 0.9605 & & & & & \\
\hline F-statistic & 0.000 & & & & & \\
\hline
\end{tabular}

Panel E: Panel regression with fixed effects for future pre-tax earnings over the components of current pre-tax earnings with $\operatorname{LPBTD}(n=7,270)$.

\begin{tabular}{|c|c|c|c|c|c|c|}
\hline $\begin{array}{c}\text { Variable } \\
(\text { EBITt+1) }\end{array}$ & Coefficients & $\begin{array}{c}\text { Standard } \\
\text { Error }\end{array}$ & T & \multicolumn{2}{|c|}{ p-value } & \multicolumn{3}{|c|}{$95 \%$ Confidence } \\
\cline { 4 - 7 } & -1.025 & 1.404 & -0.73 & 0.465 & -3.778 & 1.726 \\
\hline PLANNER & 0.1224 & 0.0268 & 4.55 & 0.000 & 0.0697 & 0.1752 \\
\hline PTCFt & 0.7758 & 1.326 & 0.58 & 0.559 & -1.825 & 3.376 \\
\hline PTCFt x PLANNER & 0.7004 & 0.0017 & 396.37 & 0.000 & 0.696 & 0.703 \\
\hline PTACCt & -0.6925 & 0.0575 & -12.03 & 0.000 & -0.8053 & -0.579 \\
\hline PTACCtx PLANNER & -0.6647 & 0.6447 & -1.03 & 0.303 & -1.9287 & 0.5992 \\
\hline _cons & 0.9605 & & & & & \\
\hline R-squared & 0.000 & & & & & \\
\hline F-statistic & & & & & \\
\hline
\end{tabular}

The aim of this study was to provide more evidence regarding book-tax differences, persistence of earnings and accruals and tax planning in the Brazilian scenario, because increase or decrease in the persistence of earnings is relevant for companies and the financial market. For example, this information can be useful to investors in reaching decisions on whether or not to invest in particular firms. Hence measuring the capacity of BDTs to predict the persistence of future results contributes to the academic literature.

In this context, the study delineated the impacts of temporary large positive BTDs on the persistence of earnings through aggressive tax planning, before and after adoption of international financial reporting standards in Brazil.

Based on the econometric models presented by Hanlon (2005) and modified by Blaylock et al. (2012), we observed the statistical significance of the regressions, which indicate a linear relation between the dependent variable and the independent variables, besides revealing the absence of multicollinearity. 
The coefficients of the variables present indications of less persistence of earnings, besides indicating that earnings became less persistent after adoption of IFRS.

With respect to the other data, the results point to the absence of multicollinearity and the coefficients of the variables indicate less earnings persistence and less persistence of the accrual components of earnings for companies that are aggressive tax planners.

The results also provide statistical evidence that temporary large positive BTDs provide useful incremental information about the magnitude of accruals and that by examining accruals it is possible to predict the persistence of earnings and their components. The results also show that LPBTDs provide useful incremental information about the effect of the magnitude of accruals on the persistence of earnings and their components after the adoption of IFRS in Brazil, specifically after 2009.

I then partitioned positive BTDs and through this approach was able to verify that the firm-year observations with large positive BTDs resulting from aggressive tax planning were associated with less persistence of earnings and the components of earnings.

The studies carried out by Raedy et al. (2011) and Guenther (2011) investigated whether specific components of BTDs can provide useful signals of the persistence of earnings by sampling firm's invoices and examining whether the numbers thus obtained provide incremental information to investors. They found evidence that specific BTDs do not appear to provide incremental information (Blaylock et al., 2012). However, this is also an issue that needs further research.

In sum, these results can lead to new studies on the themes of book-tax differences, earnings persistence and tax planning. Various other questions and/or gaps can arise, such as whether BTDs and their origins can be used by investors in pricing current profits, or whether specific components of BTDs can be useful signs of the persistence of earnings.

\section{CONCLUSIONS}

The aim of this study was to provide more evidence regarding book-tax differences, persistence of earnings and accruals and tax planning in the Brazilian scenario, because increase or decrease in the persistence of earnings is relevant for companies and the financial market. For example, this information can be useful to investors in reaching decisions on whether or not to invest in particular firms. Hence measuring the capacity of BDTs to predict the persistence of future results contributes to the academic literature.

In this context, the study delineated the impacts of temporary large positive BTDs on the persistence of earnings through aggressive tax planning, before and after adoption of international financial reporting standards in Brazil.

Based on the econometric models presented by Hanlon (2005) and modified by Blaylock et al. (2012), we observed the statistical significance of the regressions, which indicate a linear relation between the dependent variable and the independent variables, besides revealing the absence of multicollinearity. The coefficients of the variables present indications of less persistence of earnings, besides indicating that earnings became less persistent after adoption of IFRS.

With respect to the other data, the results point to the absence of multicollinearity and the coefficients of the variables indicate less earnings persistence and less persistence of the accrual components of earnings for companies that are aggressive tax planners.

The results also provide statistical evidence that temporary large positive BTDs provide useful incremental information about the magnitude of accruals and that by examining accruals it is possible to 
predict the persistence of earnings and their components. The results also show that LPBTDs provide useful incremental information about the effect of the magnitude of accruals on the persistence of earnings and their components after the adoption of IFRS in Brazil, specifically after 2009.

I then partitioned positive BTDs and through this approach was able to verify that the firm-year observations with large positive BTDs resulting from aggressive tax planning were associated with less persistence of earnings and the components of earnings.

The studies carried out by Raedy et al. (2011) and Guenther (2011) investigated whether specific components of BTDs can provide useful signals of the persistence of earnings by sampling firm's invoices and examining whether the numbers thus obtained provide incremental information to investors. They found evidence that specific BTDs do not appear to provide incremental information (Blaylock et al., 2012). However, this is also an issue that needs further research.

In sum, these results can lead to new studies on the themes of book-tax differences, earnings persistence and tax planning. Various other questions and/or gaps can arise, such as whether BTDs and their origins can be used by investors in pricing current profits, or whether specific components of BTDs can be useful signs of the persistence of earnings.

\section{REFERENCES}

Badertscher, B., Phillips, J., Pincus, M., \& Rego, S. (2009). Earnings management strategies and the trade-off between tax benefits and detection risk: To conform or not to conform? The Accounting Review. v. 84, n. 1, pp. 63-97.

Blaylock, B., Shelvlin, T., \& Wilson, R. J. (2012). Tax Avoidance, Large Positive Temporary Book-Tax Differences, and Earnings Persistence. The Accounting Review. v. 87, n. 1, pp. 91-120.

Comprix, J., Graham, R. C., \& Moore, J. A. (2011). Empirical evidence on the impact of book-tax differences on divergence of opinion among investors. Journal of the American Taxation Association. v. 33, n. 1, pp. 51-78.

Creswell, J. W. (2007). Projeto de Pesquisa: Métodos qualitativo, quantitativo e misto. 2nd ed. Porto Alegre: Artmed.

Dechow, P. M. (1994). Accounting earnings and cash flows as measures of firm performance: The role of accounting accruals. Journal of Accounting and Economics. v. 18, n. 1, pp. 3-42.

Dechow, P. M. \& Weili, G. (2006). The persistence of earnings and cash flows and the role of special items: Implications for the accrual anomaly. Review of Accounting Studies. v. 11, n. 2-3, pp. 253-296.

Dechow, P.; Ge, W.; \& Schrand, C. (2010). Understanding earnings quality: A review of the proxies, their determinants and their consequences. Journal of Accounting and Economics. v. 50, n. 2-3, pp. 344-401.

Drake, K. D. (2013). Does firm life cycle explain the relation between book-tax differences and earnings persistence? American Taxation Association Midyear Meeting: Research Forum. 
Ferreira, F. R., Martinez, A. L., Costa, F. M., \& Passamani, R. (2012). Book-tax Differences e Gerenciamento de Resultados no Mercado de Ações do Brasil, Revista de Administração de Empresas. v. 52, n. 5, pp. $488-501$.

Formigoni, H., Antunes, M. T. P., \& Paulo, E. (2009). Diferença entre o lucro contábil e lucro tributável: uma análise sobre o earnings management contábeis e gerenciamento tributário nas companhias abertas brasileiras. Brazilian Business Review. v. 6, n. 1, pp. 44-61.

Frankel, R., \& Litov. L., (2009) Earnings persistence. Journal of Accounting and Economics. v. 47, n. 1, pp. 182-190.

Graham, J. R., Raedy, J. S., \& Shackelford, D. A. (2012). Research in accounting for income taxes. Journal of Accounting and Economics. v. 53, n. 1-2, pp. 412-434, 2012.

Guenther, D. A. (2011). What Do We Learn from Large Book-Tax Differences? Working paper, University of Oregon. Available at: <http://areas.kenan-flagler.unc.edu/Accounting/TaxCenter/taxdoctoral2011/ Documents/Guenther\%20BTDs\%20010311.pdf>.

Hanlon, M. (2005). The Persistence and Pricing of Earnings, Accruals, and Cash Flows When Firms have Large Book-Tax Differences. The Accounting Review. v. 80, n. 1, p. 137-166.

Hanlon, M. \& Heitzman, S. (2010). A review of tax research. Journal of Accounting and Economics. v. 50, n. 2-3, pp. 127-178.

Healy, P. M. \&Wahlen, J. M. (1999). A review of the earnings management literature and its implications for standard setting. Accounting Horizons. v. 13, n. 4, pp. 365-383.

Jones, J. J. (1991). Earnings Management During Import Relief Investigations. Journal of Accounting Research. v. 29, n. 2, pp. 193-228.

Lev B., \& Nissin, D. (2004). Taxable income, future earnings and equity values. The Accounting Review. v. 79, n. 4 , pp. $1039-1074$.

Levine, D. M., Stephan, D. F., Krehbiel, T. C., Berenson, M. L. (2012). Estatística Teoria e Aplicações: Usando o Microsoft Excel em Português. 6th ed. Rio de Janeiro: LTC.

Lisowsky, P. (2010). Seeking Shelter: Empirically Modeling Tax Shelters Using Financial Statement Information. The Accounting Review. v. 85, n. 5, pp. 1693-1720.

Martinez, A. L. (2008) Detectando Earnings Management no Brasil: Estimando os Accruals Discricionários. Revista de Contabilidade e Finanças. v. 19, n. 46, pp. 7-17.

Martinez, A. L. (2013) Gerenciamento de resultados no Brasil: um survey da literatura. Brazilian Business Review. v. 10, n. 4, pp. 1-31. 
Phillips, J., Pincus, M., \& Rego, S. O. (2003). Earnings Management: New Evidence Based on Deferred Tax Expense. The Accounting Review. v. 78, n. 2, pp. 491-521.

Raedy, J. S; Seidman, J.; \& Shackelford, D. A. (2011). Is There Information Content in the Tax Footnote? Working paper, University of North Carolina. Available at: <http://papers.ssrn.com/sol3/papers.cfm?abstract_id=1686036>.

Santos, P. S. A., Verhagen, J. A., Bezerra, F. A. (2011). Gerenciamento de resultados por meio de decisões operacionais e a governança corporativa: análise das indústrias siderúrgicas e metalúrgicas brasileiras. Revista de Contabilidade e Organizações. v. 5, n. 13, pp. 55-74.

Schipper, K. (1989). Commentary on earnings management. Accounting Horizons. v. 3, n. 4, pp. 91-102.

Scholes, M., Wolfson, M., Erikson, M., Maydew, E., \& Shelvin, (2008). T. Taxes and Business Strategy: A Planning Approach. Prentice Hall, Fourth Edition.

Seidman. J. K. (2010) Interpreting the Book-Tax Income Gap as Earnings Management or Tax Sheltering. Working paper, University of Texas.

Sloan, R. (1996). Do stock prices fully reflect information in accruals and cash flows about future earnings? The Accounting Review. v. 71, n. 3, pp. 289-316.

Tang, T. (2006) The Value Relevance of Book-Tax Differences - An Empirical Study in China's Capital Market SSRN. Available at: <http://papers.ssrn.com/sol3/ papers.cfm?abstract_id=897120>.

Tang G, T. (2007). Book-Tax Differences, a Proxy for Earnings and Tax Management. SSRN. 2007. Available at: <http://papers.ssrn.com/sol3/papers.cfm?abstract_id=872389>.

Xie, H. (2001). The Mispricing of Abnormal Accruals. The Accounting Review. v. 76, n. 3, pp. 357-373.

Weber, D. (2009) Do analysts and investors fully appreciate the implications of book-tax differences for future earnings? Contemporary Accounting Research. v. 26, n. 4, pp. 1175-1206.

Wilson, R. J. (2009) An Examination of Corporate Tax Shelter Participants. The Accounting Review. v. 84, n. 3, pp. 969-999. 